\title{
ФРАЗЕМИТЕ СО КОМПОНЕНТА 'НЕРВ' (ЧЕШКО-МАКЕДОНСКИ ПАРАЛЕЛИ)
}

\author{
Јасминка Делова-Силјанова \\ Универзитет „Св. Кирил и Методиј“, Скопје \\ jasmin.del@flf.ukim.edu.mk
}

Фраземите во чешкиот, но и во македонскиот јазик заземаат мошне важен дел од лексичкиот фонд на јазикот. Фраземите не само што ги отсликуваат животната мудрост и искуството туку укажуваат и на човечката способност за создавање на слики и игри со зборови, од што може да се согледа не само развојот на јазикот туку и развојот на менталитетот на народот. Значително го збогатуваат јазикот и меѓучовечката комуникација, врз чија основа лежи заемното запознавање на луѓето од целиот свет. За потребите на нашиот труд најпрвин го ограничивме нашиот материјал на делата на чешки јазик преведени на македонски јазик. Од тој материјал ги извлековме фраземите што во својот состав како компонента содржат дел од човековото тело 'нерв'. Потоа, врз тој јазичен материјал направивме анализа во неколку насоки: од аспект на нивната семантика (според концептот на когнитивистичката теорија); од аспект на нивната структура (именски, глаголски, споредбени и цела реченица) и од аспект на начинот како се преведени на македонски јазик.

Клучни зборови: соматски фраземи, македонски јазик, чешки јазик, когнитивистика, превод 


\title{
IDIOMS WITH COMPONENT 'NERVE' (CZECH-MACEDONIAN PARALLELS)
}

\author{
Jasminka Delova-Siljanova \\ Ss. Cyril and Methodius University, Skopje \\ jasmin.del@flf.ukim.edu.mk
}

Idioms in the Czech and in the Macedonian language take a very important part of the lexicological fund of the language. They do not only reflect the life wisdom and experience, but they also show the human capability to create images and games with words, which can indicate not only the development of the language, but also the development of the mentality of a certain nation. They enrich the language and interpersonal communication significantly, which is the basis of mutual familiarization with the people from all around the world.

For the purposes of this paper, the material to the Czech works translated into Macedonian has been analyzed only. Out of that material phrases have been excerpted, those that contain the human body part - 'nerve'. Then, based on the language material, the analysis was performed into several directions: 1) in regard to their semantics (according to the concept of cognitive theory); 2) in regard to their structure (noun, verb, comparative clauses and whole sentence); and 3) in regard to how they have been translated into Macedonian.

Keywords: Somatic Idioms, Macedonian language, Czech language, Cognitivism, Translation 


\section{1 Вовед}

„Околниот свет е партнер во разговорот што го води нашето тело со него.“ (Hogenová, 2001)

Фраземите во чешкиот, но и во македонскиот јазик, заземаат мошне важен дел од лексичкиот фонд на јазикот. Тие се сведоштво за креативноста и снаодливоста на говорителите на дадениот јазик и кажуваат многу за духовниот живот на одреден народ, за типологијата на неговите емоции и моралните принципи, за неговиот севкупен начин на живот и поглед на свет, за неговата животна филозофија. Фраземите не само што ги отсликуваат животната мудрост и искуство туку и укажуваат на човековата способност за создавање слики и игри со зборови, од кои може да се согледа не само развојот на јазикот туку и развојот на менталитетот на народот. Значително го збогатуваат јазикот и меѓучовечката комуникација, врз чија основа лежи заемното запознавање на луѓето од целиот свет.

Еден интересен аспект во областа на соматските фраземи е тоа што, иако секој народ има исти делови на телото, од аспект на фразеологијата ги гледа на различен начин - одредени делови од телото ги сфаќа како мошне важни и ги употребува во голем број фраземи, додека други, во сопствените фразеолошки единици воопшто не ги опфаќа или ги употребува само во мал број или им дава такви пренесени значења што не одговараат на пренесените значења во другите јазици. Токму затоа е интересна јазичната слика на светот во лингвистиката, која како предмет за јазично проучување ја има поврзаноста на јазикот, културата и секојдневниот живот. Се претпоставува дека секој јазик, заедно со својата култура и со својата историска заднина, создава специфично искуство на даденото општество и учествува во создавањето специфична слика на светот за тоа општество. Тоа се однесува на начинот на кој говорителот на дадениот јазик го разбира светот во кој живее, на тоа како го вреднува тој свет, на кој начин говорителот ја доживува својата егзистенција во тој свет, а исто така, се однесува и на тоа на кој начин ги споделува своите доживувања со другите членови на своето јазично културно општество.

1.1 Во овој труд посебно се задржуваме на фраземите со компонента 'нерв'. Нервите се многубројни кончести органи во човековото тело, кои служат за пренесување импулси од нервните центри кон периферијата и обратно. Тие се посредници во управувањето и збирот на функциите на телото. Најчесто изразите се однесуваат на психичкиот живот, односно на неговите манифестации. Во продолжение ќе видиме како се објаснува лексемата 'нерв' во фразеолошките речници на чешкиот и на македонскиот јазик.

Во Речникой на современиот̄ чешки јазик (SSJČ) заглавниот збор нерв ги има следниве значења: 
1. provázkovitý útvar jdoucí z míchy n. z mozku k jednotlivým orgánům těla a zprostředkovávajíci ř́zení a souhru jeho funkci a projevů; 2. významná složka néčeho, hybná síla.

[1. кончеста формација што оди од главниот или од 'рбетниот мозок до одделните органи на телото и го пренесува управувањето и координацијата на неговите функции и изрази 2. значаен составен дел од нешто, движечка сила]

Bo Přrruční slovník českéhojazyka (PSČJ), кој претставува научен дескриптивен (описен) речник, насочен кон зацврстување на литературниот лексички фонд и на кој се работело во периодот 1935-1957 г., зборот нерв е објаснет на следниов начин:

1.vlákno spojujíci v živočišném těle dva ústroje ve funkční jednotku tak, aby se činnost jednoho sdělila druhému, převádějici na př. do ústřednich orgánů nervové soustavy podráždění a privádéjící svalům podnèty, orgán duševního života 2. smysl, nadání, zaujetí pro něco. 3. významná složka v něčem, působící jako hybná síla. 4. věc nervům zevně podobná.

[1. влакно што во телото на живото суштество поврзува две функционални единици со тоа што дејството на едната единица се пренесува на другата, на пример, до централните единици ги пренесува дразбите на допир и на мускулите им пренесува наредби, орган на душевниот живот 2. смисла, надареност, заинтересираност за нешто 3. значаен составен дел на нешто, кое дејствува како движечка сила 4. нешто/предмет што надворешно е многу сличен на нервите]

Bo Slovník české frazeologie a idiomatiky (výrazy slovesné A-P) на стр. 514516 се дадени следните фраземи со компонента нерв:

cítit něco na každém nervu - silně a nepř́ijemně něco tušit, cítit [силно и непријатно да претчувствуваш нешто];

být/bejt na nervy - být nervově nemocný a labilný [да се биде нервно болен и лабилен];

být jen pro silné nervy - být bezohledně drastický n. vzrušující a vyvolávat silné emoce [да се биде безмилосно драстичен или вознемирен и да предизвикува силни емоции];

být s nervama hotovej - být krájně znervoznělý a blízko zhroucení [да биде крајно изнервиран и близу до колапс];

být trop na nervy - být nervově nemocný, labilní, vyčerpaný a nesnášet silnější napětí [да биде нервно болен, лабилен, исцрпен и да не поднесува посилна напнатост];

hrát na nervy - silně někoho znervozňovat, draždit, lekat [некого силно да прави нервозен, да иритира, да плаши];

jit/lézt někomu na nervy - rozčilovat, dráždit někoho [лути, иритира некого];

mit na něco nervy - být nebo zastávat něco trpělivě [да се биде трпелив или да се биде трпелив кон некого];

mít nervy z kýblu - být enervovaný, nervově vyčerpaný a krájně předrazděný [да ce биде изнервиран, нервно исцрпен и крајно изиритиран];

mit nervy z ocelel mít ocelové nervy - být nervově velmi odolný a hodně snést [да се биде нервно мошне издржлив и да може многу да поднесе]; 
mit nervy ze železy - být nervově odolný a hodně snést [нервно отпорен и да може многу да поднесе];

mit jen jedny nervy - nebýt nervově, psychicky tolik n. neomezeně odolný [да не биде нервно/психички толку или неограничено отпорен];

mit pocuchané nervy - být nervově oslabený n. nemocný a projevovat to nápadnou nervozitou [да биде нервно ослабен или болен и тоа да го искажува со изразена нервоза];

mit silné/pevné nervy - být nervově odolný a hodně snést [да се биде нервно отпорен и да може многу да се поднесе];

mít slabé nervy - nebýt nervově príliš odolný a snést jen málo [да не е нервно многу отпорен и да може многу малку да поднесе];

napínat nekomи nervy - dráždit, vzrušivě napínat někoho a vyvádět ho z klidu [да иритира, некого вознемирено да напнува и да го вади од такт];

pocuhat někomu nervy - poškodit někomu dočasně nervy a narušit mu jeho nervovou rovnováhu [да му ги уништи некому привремено нервите и да му ја наруши нервната рамнотежа];

polechtat někomu nervy - př́ijemně, zábavně někoho vzrušit, napnout a trochu vylekat [пријатно, забавно некого да возбуди, да го напне и малку да го уплаши];

rvát/trhat někomu nervy- krajně někoho nervově vyčerpávat, rozčilovat a nedopřávat mu klidu [некого до крајна мера да го исцрпи, да го лути и да не му дава мир]; ztratit nervy - přestát se ovládat, ztratit sebekontrolu [да престане да се совладува, да изгуби самоконтрола].

1.2 Да ги разгледаме значењата на зборот 'нерв' во македонските речници. Во Толковниой речник на макеяонскиой јазик, том 3 (ТРМЈ), под заглавниот збор 'нерв' на стр. 375, го има следново објаснување:

нерв, $м н$. нерви, избр. мн. нерва м. 1. Секој од влакнестите органи кои се разгрануваат од главниот и од 'рбетниот мозок кон периферијата на организмот и ги примаат и пренесуваат дразбите од надворешната средина. 2. (само мн.) Целокупниот нервен систем што ги управува и ги координира дејностите на организмот.

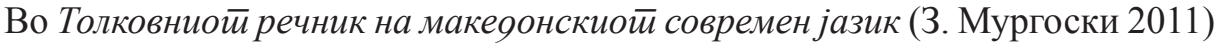
на стр. 759 е забележано:

нерв m. 1. влакно или сплет од влакна што служат за пренесување импулси на чувства или движења меѓу мозокот (или 'рбетниот мозок) и другите делови од телото. 2. нерви $p l$. а. ладнокрвност пред опасност; смелост; смиреност. б. состојба на зголемена чувствителност или нервоза: смири нерви; изгубив нерви.

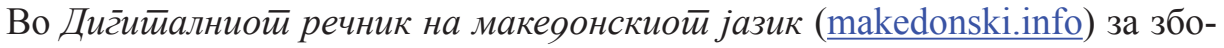
рот 'нерв’ пишува:

1. Секој од влакнестите органи кои се разгрануваат од главниот и од 'рбетниот мозок кон периферијата на организмот и ги примаат и пренесуваат дразбите од надворешната средина 2. Целокупниот нервен систем што ги управува и ги 
координира дејностите на организмот. 3. Жилички на лист на растение.

Во Фразеолошкиой речник (ФРМЈ), том 1, ги има следниве фраземи со компонента 'нерв':

без яа му зайрейери ниеgен нерв - решително и сосем смирено

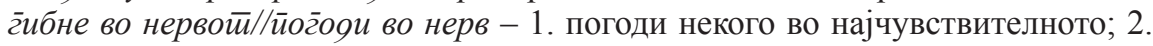

предизвика силен впечаток

$\bar{z} и$ гууби нервийе - не може да владее со себе

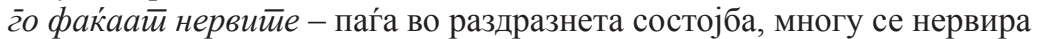

железни нерви// челични нерви - човек со силна волја, со цврста карактер

има яебели/ообри/железни/јаки/силни/челични нерви//има нерви - ладнокрвен

е, смирен е, стрплив е, може многу да поднесува

има нерв (за нешӣо) - 1. прониклив е, има моќ да забележи 2. брзо ја сфаќа

ситуацијата 3. има дарба за нешто

има слаби нерви - лесно се возбудува, раздразлив е

му г̄и кине нервите - многу го нервира, го дразни, му додева

му игрра/ояи на нервийе - му додева, го дразни, го нервира, му пречи

му оксиоирале нервите - станал нервозен

нема нерви - не може д издржи од голема душевна и нервна напнатост

си г̄u грризе/jage нервите - 1. се нервира, го губи трпението 2. психички се измачува

си иерра со нервитее (на неког̄o) - намерно го дразни, го нервира

Од претставените значења на лексемата 'нерв' може да заклучиме дека нервите се изразено поврзани со надворешниот изглед. Што се однесува до значењата на лексемата 'нерв' во чешките и во македонските речници, можеме да го забележиме следното: Во првото значење се совпаѓаат толкувањата и во македонските и во чешките речници, а тоа е дека под лексемата 'нерв' се подразбира влакно/влакна што примаат и пренесуваат дразби и импулси. Веќе во второто значење значењата почнуваат да се разликуваат. Во македонските речници второто значење се однесува на множинската форма, во значење на целокупниот нервен систем, но и ладнокрвност пред опасност, смелост или зголемена нервоза. Но, во чешките речници второто значење се толкува како: значаен дел од нешто, смисла, надареност. Ова значење во македонскиот јазик се доловува со фраземата: има нерв. Во чешките речници третото значење се однесува на предмет што е надворешно многу сличен на нервите. Додека, пак, трето значење во македонските речници е жилички на лист на растение. Се јавува уште едно значење поврзано со нервите, а тоа е состојба на зголемена нервоза.

Во однос на фразеолошките изрази со компонента 'нерв', тие се претставени како јажиња што со својата цврстина и сила сведочат за прецизна и здрава функција на нервните движења (mit nervy jako provazy // mit silné / pevné nегvу; има gебели / gобри / железни / јаки / силни / челични нерви // има нерви) или како струни што се иритираат при провокација (hrát někomu na nervy; мy игрра/оgи на нервиие)). Ако нешто не е во ред со нервите, тогаш како јажиња

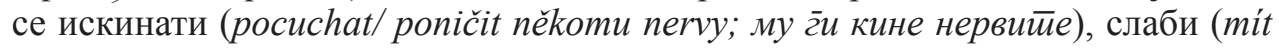
slabé nervy; има слаби нерви), можат да се искинат (selhaly/povolily /praskly 
mu nervy) или човек може сосема да ги изгуби (mít nervy v kyblu, přijit o nervy,

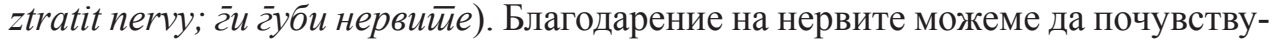
ваме ладно или топло. Преку нервите може да биде претставена и душата.

\section{2 Извори}

Овој труд е дел од пообемно истражување на соматските фраземи во преводите од чешки на македонски јазик. Материјалот за нашата анализа го извлековме од дела на чешки јазик преведени на македонски јазик. Во врска со делата што ни служеа како извори за нашиот материјал, можеме да кажеме дека на македонски јазик се преведени повеќе романи на чешки автори, една новела и неколку раскази. Иако чешката литература не е многу присутна на македонскиот книжевен пазар, сепак, можеме да кажеме дека во последниов период има извесно придвижување во однос на зголемениот интерес за превод на чешки дела на македонски јазик. Тоа посебно радува и само можеме да посакаме тој тренд да продолжи и на македонската читателска публика да ѝ се овозможи поблизу да се запознае со она што имаат да го кажат и да го понудат чешките писатели.

Изборот на дела од чешката книжевност што се преведени на македонски и што во ова истражување ни послужија да извлечеме примери на соматски фраземи се, пред сѐ, од светски докажани автори. Во овој избор на дела се наоѓа книгата Бабичка од Божена Њемцова, која е пишувана во 19 век и која изобилува со битови елементи и со многу фраземи. Дел од тие фраземи се веќе со застарена употреба, но дел сѐ уште се користат. Во овој избор има две дела од чешкиот писател Карел Чапек, кој пишува во периодот меѓу двете Светски војни, исто како и светски познатиот автор Ј. Хашек и неговиот војник Швејк. Земени се предвид и повеќе дела на М. Кундера и на Б. Храбал, и тоа дела што се пишувани во периодот од 60-тите до 90-тите години на минатиот век. Делата на М. Вивег во овој избор се најнови, односно пишувани на крајот на деведесеттите години на 20 век. Секој од овие автори има свое посебно место за периодот во кој твори и тие се од големо значење за чешката книжевност.

Од овој материјал ги извлековме фраземите што во својот состав како компонента содржат дел од човековото тело. Во овој труд ќе се задржиме на фраземите што во својот состав ја содржат компонентата 'нерв'.

\section{3 Предмет на проучување}

Од собраниот материјал на соматски фраземи со компонента 'нерв' направивме анализа во неколку насоки.

Од аспект на нивната семантика, фраземите ги разгледуваме според концептот на когнитивистичката теорија. Имено, нашето преживување е, пред cè, од телесен карактер: на каков начин реагираме на светот околу нас и како таа интеракција ја рефлектираме внатре и во односот со околината и луѓето околу нас - во голема мера е под влијание на нашиот фенотип. Овие доживувања од телесен карактер произлегуваат од фактот дека имаме специфичен поглед на светот од аспект на нашиот вид, што е даден со природноста на 
нашето тело. Со други зборови, нашата структурализација на реалноста во голема мера е дадена со нашето тело како мера.

Според фреквенцијата - освен деловите од телото што се гледаат со голо око, како главата, раката, ногата, ушите, носот и др., мошне голема и е групата на деловите од телото што се сокриени пред нашите очи, односно на внатрешните органи, коските и нервите. Значи, не може да се каже дека човекот би го перципирал своето тело само површно и дека не го рефлектира она што се случува внатре. Во оваа анализа целта е да се примени принципот на телесност на конкретен лексиколошки материјал и, притоа, да се направи семантичка класификација на фразеолошките единици. М. Џонсон и Џ. Лејкоф заеднички ги формулирале тезите за концептуалните метафори во својата книга Мейафорийе со кои живееме (2002). Книгата ја започнуваат со тврдењето дека „метафората е присутна целиот наш секојдневен живот и тоа не само во јазикот туку и во мислењето и во дејството. Нашиот обичен поимен систем, во чии рамки мислиме и како се однесуваме, во суштина, има метафоричен карактер“" (ibid.).

За принципот на телесност, она што нас нѐ интересира, централна метафора е ориентациската. Ваквата метафора го организира целиот систем на поими и тоа сите заемно во однос на себе. Таа е ориентациска, бидејќи повеќето од нив имаат нешто заедничко со ориентацијата во просторот: горе - долу, внатре - надвор, напред - назад, кон - од, длабок - плиток, централен - периферен. Овие просторни ориентации произлегуваат од околноста дека имаме тело од одреден специфичен тип и дека во нашата физичка средина овие тела функционираат на одреден специфичен начин.

Лејкоф и Џонсон го застапуваат тврдењето дека нашите основни поими, или повеќето од нив, се организирани во рамките на една просторно ориентирана метафора или поголем број такви метафори. Во врска со метафорите, авторите го потенцираат искуството - физичко и културно, општествено следствено на тоа, метафорите не се дадени случајно. Искуството е условна единица за функционирање на метафората како посредник за разбирање на поимот.

За таа цел, а според целокупниот материјал што го извлековме од делата на чешки јазик преведени на македонски, фраземите ги анализираме според следниве шеми:

- Телото како единство на своите делови: Човекот го сфаќа своето тело како целина, односно го прифаќа телото во неговата целина и разбира дека тоа функционира врз база на соработката на сите негови делови. Како луѓе, ние имаме внатрешна претстава за природноста на нашето тело, која, всушност, се базира на неговата морфологија. Телото има одредена навика и секој дел од телото има своја цел и извршува одредено дејство за кое го создал организмот. На телото не може да се најде ниту еден дел што би бил без функција или отповеќе.

- Телото како средство за броење - телото како мера: Телото, исто така, служи и како средство за броење и за одредување на некоја мера. Телото како средство за броење и мера може да изброи и конкретни нешта, како висина или должина, но и апстрактни нешта, како степен или успех. Од тоа може да 
се види дека и апстрактните значења имаме потреба да ги пренесуваме во конкретна област, а тоа е нашето човеково тело.

- Ориентација на телото во просторот: Секој ден нашето тело работи со просторот во кој се движиме, ја восприемаме нашата положба и просторна ориентација. Главата го раководи нашето тело, па затоа е неопходна и нејзина ориентација во просторот. Таа примарно е поврзана со ориентацијата нагоpe, додека ногата или петицата се поврзани со ориентацијата надолу. Оттаму произлегува дека најзначајна ориентација е опозицијата горе - долу, како и напред - назад.

- Изгледот на телото - споредба врз основа на визуелната сличност: Област што во голема мера се пројавува во соматските фраземи е изгледот на човековото тело, значи нашето визуелно искуство со нашите тела. Најизразена мера за изгледот на нашето тело е споредбата со телото на животните. Па, така, имаме раце како на мечка или долги како на мајмун, имаме очи како на газела или црвени очи како на зајак.

- Деловите на телото и нивна специфика: Оваа шема ги именува деловите од телото и нивната карактеристика. Станува збор за отсликување на она што одредени клучни зборови го отелотворуваат најинтензивно и најприродно за нас. Па, така, главата е, пред сѐ, простор каде што се случува и се сместува човековата мисла. Главата претставува сад што се полни со мисли.

- Телото како жртва / гаранција: Важноста што им се припишува на одделните делови на телото може да биде концептуализирана и во смисла на телото како жртва. Во општи рамки, важи тоа дека деловите од човековото тело можат да бидат дадени во корист на друго лице или, општо, на нешто што даденото лице го смета за важно.

Сите клучни зборови во оваа категорија укажуваат на тесната поврзаност на важноста на одделните делови на човековото тело со потребата да се потврди, да се загарантира другата страна на заедничкиот договор и да се понуди можност за евентуална санкција.

- Човеково тело = човек / Човеково тело = живот: Оваа концептуализација укажува на деловите на човечкото тело што се јавуваат како претставник кој го симболизира или целото тело или човекот како личност. Најизразно се пројавува главата во ова значење. Дел од телото може да го претставува и значењето на животот. Видовитите ја предвидуваат нашата иднина од линиите на дланката и од прстите, значи ни предвидуваат од раката.

- Телото претставува карактер - дадена особина: Со посредство на деловите на телото ги изразуваме и ги вреднуваме човечките особини. Може да се изрази непрецизноста на човековото тело, бидејќи тоа не е машина. Може да се изрази некоја состојба, карактер, особеност или слабост.

- Човековото тело и изразувањето емоции и човечки односи и врски: Нашата емоционална состојба се одразува на нашето тело. Негативната енергија ја праќаме со очите, со погледот. Човековото тело ни помага во изразувањето на заемните блиски човечки односи. Силно вкоренети во фраземите се и стравот, љубовта, спокојството, смеата, изненадувањето и чудењето. Со помош на телото можеме да ја концептуализираме и опозицијата подреденост и надреденост. Мошне силно со телото е поврзано и изразувањето казна, на- 
пад, борба меѓу две страни, природно - и затоа што се врзува на претставата за реална физичка борба.

- Телото како средство за комуникација / телото како сигнал за договор / согласување / несогласување: Во последната шема телото ни се претставува како средство за комуникација, како средство за искажување некој гест, невербална комуникација и сликовити изразувања поврзани со човековото тело. Мошне бројна група фраземи го сочинува изразувањето согласување или несогласување во рамките на комуникацијата.

3.2 Фраземите ги разгледуваме и од аспект на нивната структура (именски, глаголски, споредбени и цела реченица).

Именските фраземи се споеви составени од неколку зборови, кои самите по себе не образуваат реченица. Овие фраземи ја образуваат најшироката област и понатаму може да се делат според тоа на која зборовна група ѝ припаѓаат нејзините членови:

- придавка + именка - zlatý di̊l, černá hodinka;

- прилог + придавка - neblaze proslulý, andělsky trpélivý;

- именка + именка - jablko sváru, roh hojnosti;

- придавка + придавка - nemastný neslaný, staři mladi;

- прилог + прилог - široko daleko, kolem dokola.

Глаголските фраземи се такви фразеологизми чиј клучен збор е глаголот (mluvit do větru, dělat z komára velblouda, vzit vítr z plachet). Некои од нив имаат само постојан реченичен облик (jde to jako na drátkách, teče mu voda do bot, uhodila kosa na kámen). Тие секогаш се вклучуваат во говорниот чин и според контекстот граматички се менуваат.

Споредбените фразеологизми се мошне чести. Споредбата се наоѓ⿱ веднаш до именката (den jako ze zlata, kluk jako buk), до придавката (červený jako rak, bledýjako stěna) и до глаголот (mlči jako hrob, mluví jako kniha). Се работи за фразеолошки споредби, значи постојани со пренесени значења, а не за актуелни, слободни споредби.

Кај фраземите што се изразени со цела реченица спаѓаат поговорките, пословиците, крилатиците.

3.3 Фраземите ги разгледуваме и од аспект на начинот како се преведени на македонски јазик. Во нашата анализа на соматските фраземи со компонента нерв во преводите од чешки на македонски јазик поаѓаме од следнава поделба:

- целосен еквивалент: во оваа група спаѓаат преводни решенија што сосема се совпаѓаат со оригиналот од лексички, морфолошки и од структурен аспект;

- делумен еквивалент: во оваа група спаѓаат преводни решенија што во некој дел не се совпаѓаат сосема со оригиналот - различни лексеми или граматичка структура, но, сепак, задржана е соматската клучна компонента;

- релативен еквивалент: во оваа група спаѓаат преводни решенија во кои лексичката и граматичката структура се совпаѓаат со оригиналот, но соматската клучна компонента е заменета со друга компонента; 
- аналог: во оваа поделба оригиналната фразема е заменета со сосема различна фразема по структура, лексика и клучна компонента - задржана е само семантиката на оригиналната фразема;

- без еквивалент: во оваа група оригиналната фразема е преведена со слободен спој, описно - без фразема;

- буквален или неточен еквивалент: во оваа група влегуваат преводи што се направени буквално или, пак, неточно. При таквите извршени преводи преведувачот не сфатил дека се работи за затврднат постојан израз или воопшто не го сфатил значењето на изразот.

\section{4 Анализа на материјалот}

Во нашата анализа фраземите со компонента 'нерв' што ги извлековме од делата на чешки преведени на македонски, според значењето ги распоредивме во шемите што ги разгледавме во точка 3.1. Од сите десет шеми, фраземите од нашиот материјал според своето значење ги распоредивме во две шеми, како што може да се види од следнава анализа.

\section{1 Телото претставува карактер - дадена особина}

Карактер - особеност (Charakter - vlastnost). Со помош на нервите може да се искажат најразлични психички карактеристики и особености на човекот и нивни манифестации. Ако некој човек има нерви како кабли, тогаш велиме дека е трпелив и не се нервира толку лесно, додека, пак, ако е некој готов со нервите, тогаш велиме дека веќе не може да издржи и може да експлодира од нервоза.

4.1.1 Чешката фразема mít nervy jako provazy / špagáty // mít silné /pevné nervy // nervy z ocele / ze železa // ocelové / železné nervy (Mrhačová 2000: 88) има значење 'некој е мошне психички отпорен, не дава така лесно да биде изнервиран или изваден од рамнотежа'.

Во нашиот материјал еднаш ја сретнавме фраземата mít ocelové nervy, која на македонски е преведена со целосен еквивалент челични нерви, со значење 'човек со силна волја, со цврст карактер' (ФРМЈ 2008: 233):

K tomu je třeba ocelových nervi̊ u takového člověka... (Hašek 1984: 299)

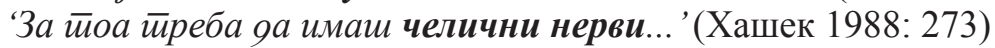

4.1.2 Чешката фразема mit železné nervy, со значење 'být psychicky velmi odolný, nevzrušivý, nenechat se ničím znervoznit/ vyvést z klidu’ (Mrhačová 2000: 88), во нашиот материјал ја сретнавме двапати. Во двата примери на македонски јазик имаме превод со целосен еквивалент железни / челични нерви: 'човек со силна волја, со цврст карактер' (ФРМЈ 2008: 233).

...chladnokrevný hrdina rodokapsů, mladý muž železných nervů krotící bandu zločinců... (Kundera 2007: 87) 
а. '...лаянокрвен херој оо булеварскитее свески, млая маж со желез-

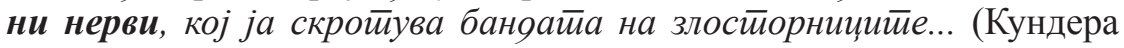
1969: 114)

б. ...лаянокрвен јунак оя аванйуристиичко романче, млая човек со жселезни нерви шито скройува баняа злостиорници... (Кундера 2007: 110)

4.1.3 Чешката фразема nemám na to/něco nervy има значење 'крај на трпението, недозволување на понатамошно нервирање'. (Mrhačová 2000: 89). Во чешкиот фразеолошки речник најдовме антоним на оваа фразема: antonym: mít na něco nervy co значењe 'být $\mathrm{n}$. zůstávat klidný a snášet něco trpělivě (a bez výbuchu zlosti n. netrpělivosti)' (SČFI 1994: 515). Во нашиот материјал ја сретнавме еднаш.

На македонски оваа чешка фразема е преведена со целосен еквивалент, кој го потврдивме и во македонските фразеолошки речници: нема нерви со значење 'не може повеќе да поднесе нешто (некој напор, состојба и др.)' (Велковска 2008: 242) и нема нерви со значење: 'не може да издржи од голема душевна и нервна напнатост’ (ФРМЈ 2008: 234).

...že na to nemá nervy a at' ho kamarádi hlídají, aby tomuhletomu... nedal přes držku. (Kundera 2007: 60)

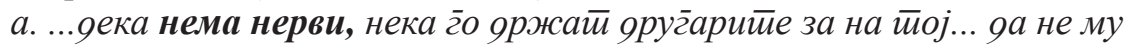
gаяе ирреку йлеќи. (Кундера 1969: 77, 78)

б. ...нема нерви за йоа и оруг̄арийе нека внимаваай qа не яобие ӣо муика овој овяе... (Кундера 2007: 74)

\section{2 Човечкото тело и изразувањето емоции и човечки односи и врски}

Непријатни чувства / негативни емоции / чувства воопшто (Nepř́́jemné/ negativní pocity/ emoce obecně). Со помош на нервите можеме да изразиме непријатни чувства, негативни емоции и психичка напнатост, кога ќе кажеме игра на нервите или hra пеrvů или, пак, ако се случува војна на нервите.

4.2.1 Во нашиот материјал ексцерпиран од дела на чешки јазик преведени на македонски го сретнавме и изразот chytnul slušnýho nerva, кој, пак, не го потврдивме во чешките фразеолошки речници. Во нашиот материјал се појави еднаш.

На македонски имаме превод без еквивалент. Евентуално, ако сакаме, сепак, фраземата да ја преведеме со фразема, сметаме дека би можело да се преведе и со гіи гууби нервииее, фразема за која сметаме дека сосема би одговарала на чешката. Ги губби нервиие со значење 'не може да се владее себеси' (ФРМЈ 2008: 233); йог̄ogu/ йог̄ояува во нервой (неког̄o): 1. погоди некого во најчувствителното; 2. предизвика силен впечаток (ibid.). Но, сепак, сметаме дека и без еквивалент, преводот е соодветен: 
Občas chytnul fakt slušnýho nerva! (Viewegh 2009: 192)

'Оовреме-навреме навистиина йолуууваше!'(Вивег 2008: 194)

4.2.2 Чешката фразема jít někomu na nervy има значење 'некој некого лути, нервира, внесува немир' (SČFI 1994: 515). Во нашиот материјал оваа чешка фразема се јавува шестпати. На македонски јазик во сите шест примери чешката фразема е преведена со целосен еквивалент, кој го потврдивме во македонските фразеолошки речници: му г̄u кине нервите со значење 'многу го нервира, го дразни, му додева' (ФРМЈ 2008: 234) и му игра (оoи, уgира) на нервитее, со значење 'му додева, го дразни, го нервира, му пречи' (ФРМЈ 2008: 234). За илустрација ќе дадеме само еден пример:

Rozvod byl chyba, kde dnes najdete kvalitniho a laskavého člověka navic vzdělaného, ale když jsme spolu žili, šel mi z neznámých důvodi̊ na nervy. (Viewegh 2009: 134)

'Развояой беше гррешка, каяе яенес ќе најяеиее квалииетеиен и ьубезен човек, ушие йак образован, но ког̄а живеевме заеяно, оя нейознатии иричини ми ооеше на нерви. '(Вивег 2008: 140)

4.2.3 Чешката фразема lézt nékomu na nervy е варијанта со исто значење како и претходната фразема, со значење 'лути, нервира некого, оди некому по нервите' (SČFI 1994: 515); jit/ lézt někomu na nervy, со значење 'nе̌co někoho silně rozčiluje, znervozňuje, zneklidňuje' (Mrhačová 2000: 89). Оваa фразема во нашиот материјал се јави еднаш.

На македонски е преведена без фразема, но со објаснувањето на значењето на фраземата: оои на нерви (некому), со значење 'нервира, предизвикува нервоза' (Велковска 2008: 242) и му игрра (оои, уяира) на нервииее, со значење 'му додева, го дразни, го нервира, му пречи' (ФРМЈ 2008: 234).

Vyprávěla mi, že ji asi opustí manžel, protože mu tak leze na nervy, že $i$ když si manžel zatím nenašel jinou, tak si mysli, že je mu lépe bez ní. (Viewegh 2009: 168)

Ми раскажуваше яека ӣо сѐ изг̄леяа сойруг̄ō̄ кंе ја найушйи, би-

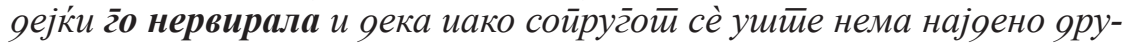
$\bar{z} a$, си мисли gека му е йоgобро без неа. '(Вивег 2008: 175)

4.2.4 Чешката фразема selhaly / povolily mu nervy (Mrhačová 2000: 89) co значење 'не се совладал, изгубил контрола' во нашиот материјал за ексцерпција ја сретнавме еднаш.

На македонски е преведена со делумен еквивалент, односно има разлика во нијансата на значење на глаголот, но сосема одговара на значењето на чешката фразема. Македонската фразема ја потврдивме во Фразеолошкиот

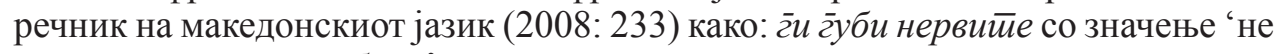
може да владее со себеси'. 
(7) Chvíli jsem se opravdu snažila, chvíli jsem ji presvědčovala a pak mi selhaly nervy. (Viewegh 2009: 201)

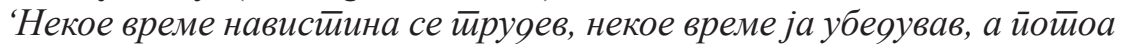
ми йойушйија нервийе. (Вивег 2008: 196)

\section{5 Заклучок}

Во нашиот материјал ексцерпиран од дела на чешки јазик преведени на македонски извлековме седум фраземи со соматска клучна компонента нерв/нерви. Четири од нив се јавуваат по еднаш, една се јавува трипати, додека една се јавува двапати и една шестпати. Тоа може да се види од следнава табела:

Табела 1. Преглед на ексцерпирани фраземи

\begin{tabular}{|c|c|c|c|c|c|c|c|c|}
\hline \multirow{2}{*}{ Бр } & \multirow[t]{2}{*}{ Соматска компонента } & \multirow{2}{*}{$\begin{array}{c}\text { Број на } \\
\text { појавувања } \\
\text { на чешката } \\
\text { фразема }\end{array}$} & \multicolumn{6}{|c|}{ Број на македонски еквиваленти } \\
\hline & & & - & $\bullet$ & $\bullet$ & $\circ$ & $\square$ & $\diamond$ \\
\hline 1. & ocelové nervy & 1 & 1 & & & & & \\
\hline 2. & železné nervy & 2 & 2 & & & & & \\
\hline 3. & nemám na to/néco nervy & $1+1$ & 1 & & & & & \\
\hline 4. & chytnul slušnýho nerva & 1 & & & & & 1 & \\
\hline 5. & jít na nervy & 6 & 6 & & & & & \\
\hline 6. & leze na ne & 3 & & 2 & & & 1 & \\
\hline 7. & selhaly nervy & 1 & & 1 & & & & \\
\hline
\end{tabular}

\section{Легенда кон табела 1.:}

- целосен еквивалент (чешкиот израз е ист со македонскиот)

- делумен еквивалент (граматичка промена во изразот)

- релативен еквивалент (промена на компонентата)

○ аналог (целосно различна фразема)

๑ безеквивалентни (нема македонски еквивалент или не бил најден)

$\diamond$ буквално или неточно преведена фразема

4.1 Две фраземи во нашиот материјал се јавуваат како именски фраземи со структура: придавка + именка (соматска клучна компонента) (4.1.1., 4.1.2.).

4.1.1 Другите се глаголски фраземи. Од нив две се со структура: глагол + предлог + именка (соматска клучна компонента) (4.2.2, 4.2.3). Една фразема е со структура: глагол + придавка + именка (соматска клучна компонента) (4.2.1) и една со структура: глагол + предлог + објект + именка (соматска клучна компонента) (4.1.3). Последната фразема (4.2.4) е глаголска фразема со структура: глагол + кратка заменска форма + именка (соматска клучна компонента).

4.2 Што се однесува до начинот на кој чешките фраземи се преведени на македонски јазик, четири од нив се преведени со целосен еквивалент (4.1.1, 4.1.2, 4.1.3, 4.2.2), една фразема е преведена со делумен еквивалент (4.2.4), додека две фраземи се преведени без еквивалент (4.2.1, 4.2.3).

4.3 Она што можевме да го извлечеме како заклучок е дека и во чешкиот и во македонскиот јазик концептот на образување на фраземите и нивната 
сликовитост е прилично блиска, што, секако, се должи на блискоста на двата јазика, како според потеклото така и според припадноста кон европската култура и сличните географски услови. Сето тоа придонесува деловите на телото на човекот да се поимаат на сличен начин и образувањето и употребата на фраземите со соматска клучна компонента и во двата јазика да имаат за основа еднаква јазична слика.

Во нашиот труд, покрај семантичка анализа, извршивме и анализа на начините на превод на чешките фраземи на македонски. Од сето она што го разгледавме, можевме да дојдеме до заклучок дека во најголем број случаи преводот е извршен со целосен или со делумен еквивалент, додека најмалку преводот е извршен безеквивалентно. Врз основа на добиените резултати од разгледаниот материјал, може повторно да се потврди тоа дека фраземите се мошне важен дел од јазикот и дека проучувањето на фразеологијата е неопходно за разбирањето на особеностите на еден народ, за неговиот поглед на светот, менталитет и начин на живот. Секој природен јазик отсликува одреден начин на концептуализација и организација на светот. Поимите што во јазикот се изразени на одреден начин, составени се од некаков систем на мислења, од еден вид колективна филозофија, која се „вградува“ како задолжителна за сите родени говорители. Голема улога во тој процес има длабоко вградената телесност во нашиот концептуален систем. Начинот на концептуализацијата на реалноста, односно на тоа како го гледаме светот, делумно е универзална, а делумно специфична, па родените говорители на различни јазици светот може да го гледаат различно низ призмата на своите јазици.

Во овој труд, токму преку споредувањето на фраземите, се обидовме да ги покажеме сличностите и разликите во поимањето на одделен дел од телото во македонскиот и во чешкиот јазик. На крајот, како заклучок, може да се забележи дека и во двата случаи има поголем број совпаѓања отколку разлики. Причината може да се бара во заедничкото словенско потекло и сличната културна основа.

\section{Библиографија}

Велковска, С. (2008). Макеоонска фразеолог̄ија со мал фразеолошки речник. Скопје: Велковска, С.

Мургоски, 3. (2011). Толковен речник на современиой макеgонски јазик. Скопје: 3. Мургоски.

Толковен речник на макеgонскиой јазик. (2006).Том трети Л-О. Скопје: Институт за македонски јазик „Крсте П. Мисирков“.

Ширилов, Т. (2008). Фразеолошки речник на макеgонскиой јазик. Том втори К-П. Скопје: Огледало.

Čermák, F., Hronek, J. and Machač J. (eds.). (1994). Slovník české frazeologie a idiomatiky. Výrazy slovesné. Praha: Academia.

Čermák, F. (2007). Frazeologie a idiomatika česká a obecná. Praha: Nakladatelství Karolinum.

Lakoff, G., Johnson, M. (2002). Metafory, kterými žijeme. 1.vyd. Brno: Host.

Mrhačová E. (2000). Názvy částí těla v české frazeologii a idiomatice. Ostrava: Spisy Filozofické fakulty Ostravské univerzity. 
Vaňková, I. (2003). O těle, smyslech, citech a prožitcích. Čeština doma a ve světě. 11 (1/2): 7-9.

Vaňková, I. (2005). Kognitivní lingvistika, řeč a poezie: (Předběžné poznámky). In: Česká literatura, Studie, 53/5: 609-637. Praha: Ústav pro českou literaturu AV ČR, v.v.i.

Vaňková, I. (2007). Nádoba plná řeči: (Člověk, řeč a přirozený svět). Praha: Nakladatelství Karolinum.

Диг̄итален речник на макеgонскиот̄ јазик. www.makedonski.info

Hogenová, A. (2001). Pohyb a vnímání. [Online] Available from: https://dl1.cuni. cz/pluginfile.php $/ 507539 / \mathrm{mod}$ resource/content $/ 1 /$ Anna $\% 20$ Hogenov $\%$ C3\%A1Pohyb\%20a\%20vn\%C3\%ADm\%C3\%A1n\%C3\%AD.pdf [Accessed: September 25th, 2020]

Přiruční slovník jazyka českého (1935-1957). Ústav pro jazyk český, v.v.i. http://psjc.ujc. cas.cz (PSJČ)

Slovník spisovného jazyka českého (2011). Ústav pro jazyk český, v.v.i. http://ssjc.cas.cz (SSJČ)

\section{Извори}

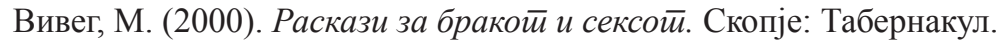

Вивег, М., Павловска, Х., Прохазкова, И. (2008). Тројиа за никаgе. Скопје: Македонска реч.

Кундера, М. (1969). Шег̄a. Скопје: Нова Македонија.

Кундера, М. (2007). Смешни љубови. Скопје: Табернакул.

Кундера, М. (2007). Шег̄a. Скопје: Табернакул.

Кундера, М. (2009). Нейоянослива леснойија на живеењейо. Скопје: Табернакул.

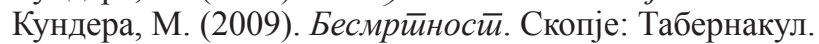

Њемцова, Б. (2009). Бабичка. Скопје: Македонска реч.

Хашек, J. (1988). Доживувањат̄а на яобриот̄ војник Швејк. книга 1 и 2. Скопје: Наша книга.

Храбал, Б. и др. (1992). Чешки хуморисииични раскази. Скопје: Македонска книга.

Чапек, К. (1977). Избрани раскази. Скопје: Култура.

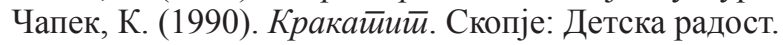

Čapek, K. (1989). Krakatit. Praha: Československý spisovatel.

Čapek, K. (1993). Povídky z jedné a z druhé kapsy. Praha: Československý spisovatel.

Hašek, J. (1990). Osudy dobrého vojáka Švejka za světové války. Díl 1, 2, 3, 4. Praha: Československý spisovatel.

Hrabal, B. (2000). Taneční hodiny pro starší a pokročilé. Praha: Mladá fronta.

Hrabal, B. (1964). Pábitelé. Praha: Mladá fronta.

Kundera, M. (2006). Nesnesitelná lehkost bytí. Brno: Atlantis.

Kundera, M. (2006). Nesmrtelnost. Brno: Atlantis.

Kundera, M. (2007). Směšné lásky. Brno: Atlantis.

Kundera, M. (2007). Žert. Brno: Atlantis.

Němcová, B. (2008). Babička. Praha: Academia.

Viewegh, M. (2001). Povídky z manželství a sexu. Brno: Petrov.

Viewegh, M., Pawlowská, H., Hercíková, I. (2009). Tři v háji. Praha: Motto.

Intercorp: projekt paralelních korpusů Filozofické fakulty Univerzity Karlovy v Praze: https://intercorp.korpus.cz/ 